\title{
アクティブラーニング支援ツール Clica を用いた学会運用支援
}

荒井研祐, ${ }^{*}$ 三堀将寛

\section{Supporting an Academic Society with the Active Learning Tool Clica}

\author{
Kensuke Arai* and Masahiro Mitsubori \\ Digital Knowledge Co., Ltd.; 5-3-4 Ueno, Taito-ku, Tokyo 110-0005, Japan.
}

(Received August 28, 2017)

\begin{abstract}
Within school classrooms, Active Learning has been receiving unprecedented attention. Indeed, Active Learning's popularity does not stop in the classroom. As more and more people argue that the Japanese government needs to renew guidelines for education, Active Learning has surfaced as a method capable of providing the necessary knowledge and training for people in all areas of society, helping them reach their full potential. It has become accepted that Active Learning is more effective over the passive listening of lectures, where there is little to no interaction. Active Learning emphasizes that learners explain their thoughts, ask questions, and express their opinions, resulting in a better retention rate of the subject at hand. In this review, I introduce an Active Learning support tool developed at Digital Knowledge, "Clica". This tool is currently being used at many educational institutions. I will also introduce an online questionnaire that Digital Knowledge provided at the 10th Annual Meeting of the Japanese Society for Pharmaceutical Palliative Care and Sciences.
\end{abstract}

Key words - Clica; education; Active Learning; academic society

\section{はじめに}

日本の教育は大きく変化することが求められてい る. 2020 年以降, 小学校, 中学校, 高校と学習指 導要領が改訂・実施される. ${ }^{1}$ また同時期に大学入 試改革が行われ，これまでの知識詰込み教育ではな い新たな教育の価值が求められている.

改訂が検討されている学習指導要領の中で, 学生 に求められる資質として強調されているのが課題解 決力である. この課題解決力を育むため注目されて るのが「アクティブラーニング（主体的・対話的で 深い学び)」である.

アクティブラーニングは, 話者（教員）による一 方向的な講義形式とは異なり, 受け手（学修者）の 能動的な学修への参加を取り入れた教授・学習法の 総称であり, 学修者が能動的に学修することによつ て, 認知的, 倫理的, 社会的能力, 教養, 知識, 経 験を含めた汎用的能力の育成を図るものである. ${ }^{2}$

株式会社デジタル・ナレッジ（１110-0005 東京都台東 区上野 5-3-4)

*e-mail: k-arai@ digital-knowledge.co.jp

本総説は, 日本薬学会第 137 年会シンポジウムS24 で

発表した内容を中心に記述したものである.
今回は，このアクティブラーニングを第 10 回日 本緩和医療薬学会年会のディベートシンポジウムに 取り入れ，登壇者のみならず参加者がそれぞれ持つ ている日々の有益な体験を, 参加者同士で主体的・ 能動的に情報提供し, 他の参加者の有益体験を自身 のノウハウとして蓄積できる参加型のディベートシ ンポジウムの実現を目指した.

\section{第 10 回日本緩和医療薬学会年会における取り組} みの概要

通常，大会場を利用したディベートシンポジウム で参加者が発言をするためには，何百〜何千人もの 人が埋め尽くされた会場で挙手をし，マイクの前ま で出て行って質問や意見をする前提で運用されるこ とが多く，慣れない人間には非常にハードルが高 い.また，運用面を考慮しても，多くの者が一度に 質問・発言をしようものならば，ディベートシンポ ジウムは成り立たない.

そこで今回, 株式会社デジタル・ナレッジの提供 する無料オンラインクリッカーサービス「Clica」 を用いて全員参加型のディベートシンポジウムを実 践した.

当該シンポジウムでは, 登壇者が発表・ディス 
カッションをしている最中であっても，参加者が自 身のスマートデバイスを用いた bring your own device (BYOD) 方式でオンラインのディスカッ ションエリアに参加できるように設計を行った。 今 回は一般的なクリッカー活用にみられる択一問題へ の回答ではなく，文字入力による自由記述での発言 を重視し運用を行った。

\section{利用者の環境}

事前に SNS を使って，ディベートシンポジウム にてスマートデバイスを使うことを告知し，イン ターネットに接続可能な端末としてスマートフォ ン・タブレット等を持参することを指示した。会場 では，事前配布資料にハンドアウトを追加し，シス テムへのアクセス情報を通知した．またシステムへ のアクセスには参加者のスマートフォンを用いて二 次元コードを読み込ませ，システムのURLや ID ・パスワードなどを入力する手間を省かせ，導 入に関するハードルを下げた。無料オンラインク リッカーサービス「Clica」は，マルチデバイスで の利用に対応しているため, 様々な端末・ブラウザ からアクセスをすることが可能であり，利用者の環 境に大きく依存しないことも大きな特徴である.

\section{利用者の反応}

2016 年 6 月 3 日から 6 月 5 日まで，アクトシ ティ浜松にて開催された第 10 回日本緩和医療薬学 会年会の合計 6 講演にてディベートシンポジウム運 用を行った。それぞれ講演毎にシステムを個別に用 意し，最大で約 1000 名規模の会場での利用を想定 したシステムを構築した。参加者は，講演中に登壇 者の発表に対する意見や質問を投稿可能になる，参 加者各々が講演内容を聞くだけの受け身な姿勢でな く，自身の「経験」「ナレッジ」を共有し，かつ バックボーンの違う他の参加者の「経験」「ナレッ ジ」を自らインプットする姿勢を感じることができ た。 以下に，会期中に投稿された内容を数件抜粋す る.

「神経障害疼痛に対し鎮痛補助薬の効果があれば 内服薬の継続でもよいかと思いますが，どのような 患者に神経ブロックが適応になりますか？ 緩和 チームとして積極的に提案してもいいのでしょう か？ また，効果時間や使用頻度なごご教授くださ い」。これは登壇者に対する質問である。このよう にシステム上に質問を投稿させることによって，実
際のシンポジウムを中断することなく，質問を受け 付けることができる. またオンライン上にエビデン スとして残されることにより，登壇者が持ち時間終 了後であってもシステム上で回答をする選択肢が持 てることもメリットの1つである.

「認定薬剤師になるための条件に学会員でなけれ ばならないというのがある，薬剤師の認定，専門が 世のなかの位置付けとしてどう評価されているのか. feeがつくようになるとさらに無駄に学会に入会し て年会に参加しなければならなくなりそう」。これ は参加者が自分の意見を発言している例である．こ のように自由に発言をさせることが可能になってい るため, これにより参加者同士による密接なコミュ ニケーション・ディスカッションが発生するケース もみられ，非常に有意義であったと考える。

また，同会では PC やスマートフォン等を利用 し，オンラインで回答可能なアンケートを実施して いる. その項目の一部についても触れたい.アン ケートは，e-ラーニングシステムのアンケート機能 を用い，参加者が自由なタイミングで回答できる形 式をとった．参加者 2634 名中，438 件の有効回答 を得た。

全回答中，システムを活用したディベートシンポ ジウムについて，5択のアンケートの中で $63 \%$ の参 加者が「あったほうがよい」と回答している. 「あったほうがよい」と回答した参加者の声を紹介 すると，「質問が簡潔になり，無駄な質問者に時間 を割くことがなく，できるだけ多くの討議ができる と感じた」というような，シンポジウム運営自体が 効率的になるとする声や，「同じ論文でも 2 通りの 見方があった．医者と話すときの参考になった」， 「各施設によって環境は全く違うため，思わぬ意見 が聞けたりする」といつたように他の参加者の発言 から普段自分を取り巻く環境では得られないような 気付きを得られることのメリットを指摘する声が目 立つた。

\section{課題と反省点}

ポジティブな意見が多いが，ネガティブな意見が ないわけではない.

「ディベートになっていなかったのでわからな い.するならもつとできる司会者が必要」，「電波悪 すぎて，携帯がほとんど使えなかつた．運営側の不 慣れさもあったのか，壇上での右往左往具合が目 
立つた」. 以上からもわかる通り, 主に今回課題と なつた点は 2 点ある. 1 点はシンポジウムを進行す る人間のスキルについてだ。通常通りシンポジウム を進行しながらシステムに投稿された意見や発言を ピックアップし即座にフォローすることは簡単なこ とではない，そこには慣れやセンスを必要とする. そのため, 課題としてはシンポジウムの進行とシス テム上での投稿内容を俯瞰できる第三者のコーディ ネーターの配置の必要性である. 登壇者自身だけで なく, 俯瞰できる立ち位置にシステムの発言内容を チェックする者を配置することにより, 円滑に進行 管理ができるようになる.

2 点目は会場のネットワークの問題である.これ は, 年会設計初期にシステムの導入が決まっておら ず，ネットワークの遮断性が高い会場にてシンポジ ウムの多くを実施したために発生している. 大規模 会場でシステム導入する場合には会場の選定段階で 意識をしたい.
利益相反荒井研祐（株式会社デジタル・ナ レッジの社員), 三堀将寛（株式会社デジタル・ナ レッジの社員).

\section{REFERENCES}

1) Ministry of Education, Culture, Sports, Science and Technology. "Schedule for upcoming educational guideline revisions.": 〈http: //www.mext.go.jp/a_menu/shotou / new-cs / __ icsFiles / afieldfile / 2017 / 05 / 12 / 1384662_1_1.pdf $\rangle$, cited 25 July, 2017.

2) Ministry of Education, Culture, Sports, Science and Technology. "Revision Points.": 〈http: //www.mext.go.jp/a_menu / shotou / new-cs /__ icsFiles / afieldfile / 2017 / 06 / 16 / 1384662_2.pdf $\rangle$, cited 25 July, 2017. 